\title{
Life Satisfaction as A Determinant of Loneliness Among College Students
}

Sabina Salkic

Munich, Germany

ARTICLE INFO

Keywords:

Life Satisfaction

Loneliness

Social Contacts

\begin{abstract}
Loneliness is usually defined as an unpleasant and emotionally disturbing subjective experience that occurs as response to the discrepancy between desired and achieved levels of social contact. The experience of loneliness is unpleasant and painful experience, followed by feelings of rejection from the people that we care, with simultaneous desire that they accept us and to be part of their lives.

The sense of global life satisfaction stems from cumulative successes in a variety of specific situations. The measure of overall satisfaction with one's life reflects in addition to the successes experienced, the average level of mood of the person, that is, his emotional state over a long period or even throughout an individual's life. As such, overall life satisfaction is an indicator of quality of life and emotional adjustment.

The main aim of this study was to examine the relationship between the life satisfaction with loneliness.

The study was conducted on a sample of 200 students (82 males and 118 females) of various departments of the final year of Social Sciences and Technical Sciences at the University of Tuzla, Bosnia and Herzegovina.

The study applied the following instruments: The scale of general life satisfaction; The short version of UCLA loneliness scale.

The results showed a negative relationship of loneliness with life satisfaction among students $(\mathrm{r}=-.515, \mathrm{p}<.05)$. The obtained results show that the higher the life satisfaction of students, the less loneliness it is and vice versa. It can be concluded that students who achieved high scores on the life satisfaction scale showed less loneliness, while students who scored low on the life satisfaction scale showed higher loneliness.
\end{abstract}

\section{Introduction}

\subsection{Life satisfaction}

Life satisfaction - implies a cognitive assessment of one's life in the form of a person's general judgment about the different domains of one's life, while affective components - a pleasant and unpleasant affect, represent a basic experience of current events in people's lives. Pleasant experiences are desirable and valuable, so a person who experiences pleasant emotional experiences perceives their life as valuable and positive. People with high levels of subjective well-being have predominantly positive evaluations of their own lives and circumstances (Diener, 2000, according to Vasic, Sarcevic, and Trogrlic, 2011).

* Corresponding author E-mail address: sabinasalkic025@gmail.com 
The sense of global life satisfaction stems from cumulative successes in various specific situations (Bezinović, 1988, according to Jerković, 2005). The measure of overall satisfaction with one's life reflects, in addition to the successes experienced, the average level of a person's mood, that is, their emotional state over a long period or even throughout the individual's life. As such, overall life satisfaction is an indicator of quality of life and emotional adjustment. Persons who are securely attached have an average higher mood level, are less depressed, and mostly experience pleasant emotions, and they will also show greater overall satisfaction with their lives (Jerković, 2005).

Research suggests that the well-being of an individual is much more influenced by social contacts, emotions, and personal satisfaction than income and material things. Life satisfaction, personal happiness and quality of life are different components of what is called subjective well-being. Life satisfaction is a complete perception and evaluation of one's life and is most often described as a cognitive component of subjective well-being, while on the other hand, feeling happy is an emotional component and is described as a frequent feeling of positive emotions (Diener; according to Petrov et al., 2011). Quality of life in this context could be described as satisfaction with particular areas of life, such as work, family, standard of living, health and the like.

The sense of happiness, according to some authors (Brajković, 2010), in addition to satisfaction with life, includes other elements such as hope, emotional stability, the existence of moral principles. The authors equate the notion of subjective well-being and happiness. They describe a happy person as mentally and socially adjusted, which means that the person has high self-confidence, emotional stability and is socially involved.

Life satisfaction according to Penezić (1999; according to Brajković, 2010) is related to a person's mental health. It refers to the overall assessment of a person's life or to a comparison that reflects a perceived discrepancy between a person's aspirations and achievements. Life satisfaction is a cognitive evaluation of all life.

When trying to determine the relationship between loneliness and life satisfaction, negative correlations are usually obtained.

Examining life satisfaction at any age is a new concept in psychology and until a few decades back it did not attract the interest of psychologists. Most research in the field of scientific psychology has neglected to examine subjective well-being, happiness, quality of life, and subjective perception of the world. Psychologists rarely think about what makes people happy. Instead, they are focused on what makes them sad or worried. By developing the socalled positive psychology, there is an increasing interest among psychologists in examining the factors that contribute to quality of life as well as life satisfaction.

\subsection{Loneliness}

An important set of factors that can affect health are those related to the domain of social functioning, such as the size of the social network, the frequency of social contacts, social support, social isolation, loneliness and solitude. Psychosocial functioning can be an important factor in shaping the assessment of one's health.

The experience of loneliness is an unpleasant and painful experience, and it is accompanied by a sense of rejection from the people we care about, with a desire to be accepted and be part of their lives. One of the main reasons we feel lonely is to feel that we are psychologically alone, despite the fact that other people are around us because we have not made close relationships with them.

\section{Materials and Methods}

2.1. The goal of research 
To our knowledge, the direct link between life satisfaction and loneliness has not been explored so far. Given the lack of research into these constructs in young adulthood, this study aims to determine their relationships in a sample of final-year college students.

Thus, the main aim of this research was to determine the relationship between life satisfaction with loneliness, on a sample of students.

\subsection{Research tasks}

In relation to the aim of the research, the task is as follows:

- Examine whether there is an association between life satisfaction and loneliness

\subsection{Research hypotheses}

H1 Research to date has shown that life satisfaction is significantly correlated with various constructs and loneliness. Therefore, we can assume that there is a statistically significant correlation between life satisfaction on the one hand and loneliness level on the other.

\subsection{Research variables}

Given the content and structure of this research, the variables are as follows:

- Dependent variable: loneliness

- Independent variable: life satisfaction.

\subsection{Description of the research}

The examination was conducted within the University of Tuzla. Prior to the examination itself, permission was sought for student testing. The examination was carried out in groups, in agreement with professors / assistants, at the beginning of regular lectures at the faculty. Before submitting the questionnaire, students were told to participate in a research paper to produce a master's thesis. Students were advised that the test results would be used for research purposes and that they were anonymous. Afterwards, questionnaires were distributed to students and detailed instructions were written. Respondents were given sufficient time to answer the questionnaires, but also to ask questions if there were ambiguities.

\subsection{Sample of respondents}

The study was conducted on a suitable sample of respondents. Students from different departments of the final years of study of social and technical sciences at the University of Tuzla participated in the examination. The final years of the study were taken because students had already formed social networks by that time and in order to avoid potential mistakes and obtain relevant results.

The total number of respondents to the survey was 200 , of which $82(41 \%)$ were male and $118(59 \%)$ were female.

For the variable section of study (science of study) we have data on 200 students, of which $100(50 \%)$ are in social sciences and $100(50 \%)$ are in technical sciences.

The average age of the respondents was 22.8 years (range $21-32$ ).

\subsection{Measuring instruments}

The following measuring instruments were used in this study:

- The scale of general life satisfaction (Bezinović, 1988) is a measure of general adaptation to living conditions. It contains 7 statements rated on a scale of 1 to 5. Four statements relate to the global sense of happiness, one to life satisfaction (particle number 2) and one to depression (particle number 6). Two claims were made in the negative direction (particles number 5 and 6). The result is obtained by summing the answers, with the reverse scoring of the answers to the two statements. A higher score also indicates greater satisfaction with life. 
Since all claims measure practically the same phenomenon, the internal reliability coefficient, Cronbach's alpha, obtained on a sample of students is very high and amounts to 0.92 (Bezinović, 1988). The score ranges from 7 to 35.

- A short version of the UCLA Loneliness Scale

One-dimensional and multidimensional scales are used to measure loneliness. The most commonly used is the UCLA Loneliness Scale (Russell et al., 1980, according to LackovicGrgin et al., 2002), which measures global loneliness understood as a condition. However, numerous studies show that this scale is not one-factor and the number of factors varies from sample to sample. Also, as regards gender differences in loneliness, consistent results were not obtained on different samples of respondents. That is why Allen and Oshagon (1995, according to Lackovic-Grgin et al. 2002) proposed a short form of the UCLA scale containing seven particles. The scale is one-dimensional and proved to be invariant with respect to different characteristics of the respondents (by age, gender, race, education, economic status). The scale was also used on samples of Croatian participants - high school students, students, younger and older adults. The scale contains seven statements that are answered on a five-point Likert-type scale (1 to 5). The total result is formed as a linear combination of results in each individual particle. A higher score indicates higher loneliness. The Cronbach alpha-type reliability coefficients ranged from .83 to .85 , which is quite satisfactory given the small number of particles (Lackovic-Grgin et al. 1998; 1998a, according to Lackovic-Grgin et al. 2002). Scores range from 7 to 35.

\subsection{Data processing methods}

Descriptive statistics methods were used for statistical data processing. After editing and coding, the collected data was entered into the data matrix in the SPSS program database. The data processing was done using the statistical software SPSS 16.00 for Windows. The association test was performed using correlation and multiple regression. All survey results were conducted at a significance level of 0.05 .

\section{Results}

In order to access data processing, it was necessary to check that the results on the scale of life satisfaction and loneliness were distributed according to the principles of normal distribution. For this purpose, the Kolmogorov-Smirnov (K-Sz) distribution normality test was applied.

Table 1.

Minimum and maximum values, arithmetic mean, standard deviation and results of the normality distribution test $(K-S z)$ for the results on the scales used in the study

\begin{tabular}{lcccccc}
\hline & $\operatorname{Min}$ & $\operatorname{Max}$ & $M$ & $S D$ & $K-S z$ & $p$ \\
\hline Life satisfaction & 7.00 & 35.00 & 28.94 & 5.34 & 0.12 & .000 \\
Loneliness & 7.00 & 35.00 & 14.04 & 6.23 & 0.12 & .000 \\
\hline
\end{tabular}

It can be seen from Table 1 that the scores on the scales deviate statistically significantly from the normal distribution. Distributions on the Life Satisfaction Scale are negatively asymmetrical, while on the Loneliness scale it is positively asymmetric, which is to be expected, since most respondents achieved lower scores on the Loneliness Scale (higher scores indicate higher levels of loneliness).

Distributions of scores on the Life Satisfaction scale are negatively asymmetric, while the distribution of scores on the Loneliness scale is positively asymmetric, but the obtained values of the asymmetry and flatness index are within acceptable ranges (asymmetry $<1 \mid$, 
flattening $<|3|$ ). It is considered possible to use parametric statistics if the distributions are relatively regular (not bimodal or U-shaped) and that the samples are sufficiently large and of similar size (Petz, 1997).

Table 2.

Descriptive parameters for the results obtained on the loneliness scale

\begin{tabular}{lccccc}
\hline & $\mathrm{N}$ & Min & Max & M & SD \\
\hline Total loneliness & 200 & 7.00 & 35.00 & 14.04 & 6.23 \\
Valid N & 200 & & & & \\
\hline
\end{tabular}

$\mathrm{N}$ - number of respondents; Min - the minimum score on the loneliness scale; Max - the maximum score on the loneliness scale; $\mathrm{M}$ - arithmetic mean; SD - standard deviation

Table 2 shows the descriptive parameters for the obtained results on the loneliness scale. The arithmetic mean on the Short Version of the UCLA Loneliness Scale is 14.04, and the standard deviation is 6.23.31 subjects scored a minimum of 7 points and a maximum score of 35 , or more precisely 1 respondent has 35 points. The most frequent result is 10 or 18 respondents out of 10 points, and on this basis, we can conclude that our respondents generally have a low level of loneliness.

Table 3.

Reliability coefficients of the scales used for hypothesis testing purposes

\section{Cronbach $\alpha$}

\begin{tabular}{cl} 
Life satisfaction & .75 \\
Loneliness & .86 \\
\hline
\end{tabular}

The Cronbach $\alpha .70, .80$, and .90 reliability coefficient values tell us how reliable the scales are. The coefficient value of .70 is the lower limit of acceptable reliability, the value of 0.80 is acceptable, ie good reliability, and .90 is the highest reliability.

The reliability coefficients, Cronbach $\alpha$, of the General Life Satisfaction Scale on previous research were .88, .92 (Jerković, 2005; Bezinović, 1988), and in this study it is .75, which is quite satisfactory given the small number of particles.

The reliability coefficients, Cronbach $\alpha$, for the Short version of the UCLA Loneliness Scale in earlier studies ranged from .83 to .85 (Lackovic-Grgin et al. 1998, 1998a), while in this study it was .86 (Table 3 ), which shows good scale reliability.

\subsection{Examining the association between life satisfaction and loneliness}

To determine whether there is a correlation between life satisfaction and loneliness, a correlation between the above variables was calculated.

Table 4.

Descriptive parameters for scores on the life satisfaction scale

\begin{tabular}{lccccc}
\hline & N & Min & Max & M & SD \\
\hline Total life satisfaction & 200 & 7.00 & 35.00 & 28.79 & 4.99 \\
Total loneliness & 200 & 7.00 & 34.00 & 14.04 & 6.23 \\
Valid N & 200 & & & & \\
\hline N-
\end{tabular}

$\mathrm{N}$ - number of respondents; Min - the minimum score on a scale; Max - the maximum score on a scale; $\mathrm{M}$ arithmetic mean; SD - standard deviation 
Table 4 shows the descriptive parameters for the results obtained on the life satisfaction scale. The arithmetic mean on the scale is 28.79 and the standard deviation is 4.99 . A minimum of 7 points was scored by one respondent, and the maximum achieved score was 35 , or more precisely 22 respondents got 35 points, which is also the most frequent score.

Table 5.

Coefficients of correlations between life satisfaction and loneliness in students $(N=200)$

\begin{tabular}{llcc}
\hline & & $\begin{array}{c}\text { Total } \\
\text { loneliness }\end{array}$ & $\begin{array}{c}\text { Total life } \\
\text { satisfaction }\end{array}$ \\
\hline Total loneliness & Spearman coefficient & & -.515 \\
& $\mathrm{p}$ & & .000 \\
Total life satisfaction & Spearman coefficient & -.515 & \\
& $\mathrm{p}$ & .000 & \\
\hline
\end{tabular}

The relationship between life satisfaction (as measured by the SCI scale) and loneliness (measured on the UCLA scale) was investigated using the Spearman linear correlation coefficient. Preliminary analyzes were performed to prove that the assumptions of normality, linearity, and homogeneity of variance were met.

A strong negative correlation between the two variables, $\mathrm{r}=-. .515, \mathrm{n}=200, \mathrm{p}<.0005$, was calculated, with a high level of life satisfaction followed by a low level of loneliness, and hypothesis $\mathrm{H} 1$ assuming "statistically significant the correlation between life satisfaction on the one hand and the level of loneliness on the other "accepts.

Previous research (Ozben, 2013; Bugay, 2007; Tümkaya, Aybek, \& Çelik, 2008) has also shown a negative correlation between life satisfaction and loneliness in college students.

\section{Discussion}

The relationship between life satisfaction (as measured by the SCI scale; scores range from 7 to 35) and loneliness (measured by the UCLA scale; scores ranging from 7 to 35) was investigated using Spearman's linear correlation coefficient. A really significant negative correlation between the two variables was calculated $(\mathrm{r}=-.515, \mathrm{p}<.05)$, with a high level of life satisfaction followed by a low level of loneliness.

The obtained results show that the higher the life satisfaction of students, the less loneliness it is and vice versa. It can be concluded that students who scored high on the life satisfaction scale showed less loneliness, while students who scored high on the life satisfaction scale showed higher loneliness.

When trying to determine the relationship between loneliness and life satisfaction, negative correlations are usually obtained (Brajković, 2010).

Ozben (2013) also found a negative association between loneliness and life satisfaction in students $(\mathrm{N}=525)$ of Turkish University.

\section{Conclusion}

A statistically significant negative association between loneliness and self-esteem, as well as loneliness and life satisfaction, was found. We conclude that the level of loneliness is lower in people who have a higher level of self-esteem, that is, people with low self-esteem have a higher level of loneliness, and that a high level of life satisfaction is accompanied by a low level of loneliness. 


\section{References}

Brajković, L. (2010). Pokazatelji zadovoljstva u trećoj životnoj dobi. Disertacija. Zagreb: Medicinski fakultet.

Bugay, A. (2007). Loneliness and Life Satisfaction of Turkish University Students. http://www.iscet.pt/sites/default/files/obsolidao/Artigos/Loneliness\%20and\%20Life\%20S atisfaction\%20on\%20Turkish\%20University\%20Students.pdf accessed 10.09.2015.

Jerković, V.(2005).Privrženost i psihološka prilagodba studenata. Diplomski rad. Zagreb: Filozofski fakultet.

Lacković-Grgin, K, Penezić, Z., Sorić, J. (1998). Usamljenost i samoća studenata: uloga afilijativne motivacije i nekih osobnih značajki. Društvena istraživanja, 7(4-5), 36-37.

Ozben, S. (2013). Social skills, life satisfaction, and loneliness in Turkish university students. https://www.sbp-journal.com/index.php/sbp/article/view/2407 accessed 16.09.2015.

Penezić, Z. (2006). Zadovoljstvo životom u adolescentnoj i odrasloj dobi. Društvena istraživanja, 15(4-5), 84-85.

Petrov, J., Hadži-Pešić, M., Zlatanović, Lj., Milenović, M. (2011). Zadovoljstvo životom, zadovoljenje osnovnih psiholoških potreba i sklonost ka psihosomatici. Godišnjak za psihologiju, 8(10), 105-124.

Petz, B. (1997). Osnovne statističke metode za nematematičare. Zagreb: Naklada Slap.

Tümkaya, S., Aybek, B., Çelik, M. (2008). An investigation of students' life satisfaction and loneliness level in a sample of Turkish students. http://www.jhumansciences.com/ojs/index.php/IJHS/article/view/429/278 accessed 14.09.2015.

Vasić, A., Šarčević, D., Trogrlić, A. (2011). Zadovoljstvo životom u Srbiji. Primenjena psihologija, 2, 151-177. 